\title{
Investigating Citizens' Concern About Corruption and Anti-corruption: A Case Study in Vietnam ${ }^{3}$
}

Submitted: 17.06.2021. Accepted: 23.10.2021

\begin{abstract}
Corruption has been the centre of attention on a global scale. Almost all studies concentrate on corruptive effects on the governance, economics or politics. This paper investigates the citizens' perceptions towards corruption and anti-corruption in Vietnam. This is a new look contributing to the panoramic picture of anti-corruption. The study employed a descriptive approach with a researcher-made questionnaire for 385 respondents selected by a stratified random sampling method based on Cochran's formula. It was found out that preventive measures and corruption laws are not severe enough to admonish corruption offenders. Transparency is not highly promoted for people to access information, so citizens' supervision is not very effective. There is a mismatch between citizens' perceptions and external organisations' assessment. It is necessary to implement anti-corruption law strictly and renovate people's right to get corruptive information. Moreover, the government should recheck and adjust preventive anti-corruption laws to match each specific type of corruption. Urgently, the operation of the state apparatus ought to cooperate and join hands to combat corruption. It is advisable for the government to collaborate with external organisations to exchange experience in curbing corruption.
\end{abstract}

Keywords: corruption, anti-corruption, offender, transparency, preventive measures.

$1 \quad$ Ph.D. Tuan Van Vu - Hanoi Law University (Vietnam); e-mail: tuanvv@hlu.edu.vn; ORCID: 0000-0002-3066-7338.

2 Assoc. Prof. Oanh Thi Cao - Hanoi Law University (Vietnam); e-mail: oanhhs@hlu.edu.vn; ORCID: 0000-0002-9046-4479.

3 This paper is financially supported by Hanoi Law University, Vietnam. 


\section{TUAN VAN VU, OANH THI CAO}

\section{Badanie postrzegania przez obywateli zjawiska korupcji i jej zwalczania. Studium przypadku w Wietnamie ${ }^{4}$}

\section{Streszczenie}

Korupcja znalazła się w centrum uwagi na skalę globalną. Niemal wszystkie badania skupiają się na jej szkodliwych skutkach w odniesieniu do rządów, ekonomii i polityki. Niniejszy artykuł bada to, jak obywatele postrzegają korupcję i antykorupcję w Wietnamie. To nowe spojrzenie przyczyniające się do szerokiego ujęcia problematyki antykorupcji. Badanie ma charakter opisowy, do jego przeprowadzenia wykorzystano autorską ankietę dla 385 respondentów, wybranych metodą losowania warstwowego w oparciu o wzór Cochrana. Okazało się, że środki zapobiegawcze i przepisy dotyczące korupcji nie są wystarczająco surowe, by stanowiły przestrogę dla sprawców korupcji. Transparentność nie jest promowana na tyle mocno, by ludzie mieli dostęp do informacji, więc kontrola obywatelska nie jest zbyt skuteczna. Istnieje niezgodność między postrzeganiem korupcji przez obywateli a tym, jak oceniają ją organizacje zewnętrzne. Konieczne jest ścisłe wdrożenie prawa antykorupcyjnego i odnowienie prawa obywateli do uzyskiwania informacji dotyczących korupcji. Co więcej, rząd powinien ponownie sprawdzić przepisy dotyczące zapobiegania korupcji i dopasować je do każdego rodzaju korupcji. Działanie aparatu państwowego powinno się pilnie oprzeć na współpracy i połączeniu sił w celu zwalczenia korupcji. Wskazane jest, by rząd nawiązał współpracę z organizacjami zewnętrznymi w celu wymiany doświadczeń w kwestii ograniczania korupcji.

Słowa kluczowe: korupcja, antykorupcja, przestępca, transparentność, środki zapobiegawcze.

4 Artykuł uzyskał wsparcie finansowe Hanoi Law University (Wietnam). 


\section{Introduction}

The unsolvable problem of corruption has drawn much attention to all nations. It is not only the concern of governmental bodies and domestic bodies but also the international agencies. In every country, they found their own bodies for the anti-corruption to cope with the corruption law, and to cooperate with international agencies to address the corruptive issues. Obviously, corruption has far-reaching, negative consequences that pose decay and threaten the stability and security of societies, undermine the institutions, devalue the democracy, deteriorate the ethical values and justice, jeopardise the sustainable development, and weaken the rule of law. Realising the seriousness of problems and dangers, the United Nations commemorates the International Anti-corruption Day on 9 December to highlight the footprint of the United Nations Convention against Corruption. This convention acknowledges that corruptive problems are no longer considered as a local matter but a transnational phenomenon influencing all societies and economies which requires all nations to closely collaborate to prevent and combat the corruption.

Corruptive information is politically sensitive, so it is considered as secure and hazardous to the public concerns. For the sake of better access to the corruptive prevention, many organisations, such as the National Anti-Corruption Commission (NACC), non-governmental organisations (NGOs), the United Nations (UN), Transparency International (TI), and the World Trade Organization (WTO), have done their best to supply citizens with state-of-the-art materials relating to the anti-corruptive policies. For the past decades, many researchers ${ }^{5}$ have examined the seriousness of the corruptive problems in different aspects such as the impacts of corruption on economic prosperity, foreign direct investment (FDI), government regulation or social trust. Corruption is regarded as dishonest or illegal behaviour, especially of people in authority $\left(\mathrm{OALD}^{6}\right)$. Transparency International (TI) - a global movement working in over 100 countries to end the injustice of corruption - defines

5 E.g. V. Alfano, S. Capasso, R.K. Goel, EU accession: A Boon or Bane for Corruption?, "Journal of Economics and Finance" 2020, 45(1), pp. 1-21; S. Gil-Pareja, R. Llorca-Vivero, J.A. Martínez-Serrano, Corruption and International Trade: A Comprehensive Analysis With Gravity, "Applied Economic Analysis" 2019, 27(79), pp. 3-20; C.P. Kratcoski, M. Edelbacher (eds.), Fraud and Corruption, Cham 2018; L. Tingting et al., The Dark Side of Transparency in Developing Countries: The Link Between Financial Reporting Practices and Corruption, "Journal of Corporate Finance" 2021.

6 Oxford Advanced Learner's Dictionary, 10th ed., Oxford 2020. 
corruption as the abuse of entrusted power for private gain. TI asserts that corruption decreases trust, jeopardises democracy, hinders economic development and further worsens inequality, poverty, social division and the environmental crisis. Similarly, the UN assesses that corruption is seen as an insidious plague which has a variety of corrosive effects on societies. Corruption erodes democracy and the rule of law, results in violations of human rights, distorts markets, undermines the quality of life, and enables organised crime, terrorism and other threats to human security to thrive. In fact, corruption takes various forms which are recognised severely in developing countries. ${ }^{7}$

This study discusses seven common categories of corruption, such as bribery, embezzlement, facilitation payment, fraud, collusion, extortion, patronage, clientelism and nepotism. In particular, bribery is committed when an amount of money or something valuable is offered to somebody in order to gain their support, especially by doing something dishonest. In other words, bribery is the act of dishonestly persuading someone to do something for one's favour by receiving a payment or another inducement. Inducements can be gifts, loans, fees, rewards or other advantages (taxes, services, donations, etc.). The hazardous use of bribes can result in collusion (e.g. inspectors under-reporting offences in exchange for bribes) and/or extortion (e.g. bribes extracted against the threat of over-reporting). ${ }^{8}$

Embezzlement can be viewed as another category of corruption. It takes the form of stealing, misdirecting or misappropriating funds or assets which were placed in one's trust, under one's control or belonged to employers' rights. From the legal stance, embezzlement does not need to involve corruption, i.e. the embezzlement can occur when a defendant either withholds the personal property or transfers it to a third party. In some cases, embezzlers peculate public property with a small amount over a particular time interval so as not to be caught. Many embezzlers steal a very large amount of the goods or funds on a single instance with the intention of vanishing off the face of the earth. Otherwise, company

7 T. Murray, Corruption in Developing Countries: What Keeping It in the Family Means for Everyone Else, "Osgoode Hall Law Journal" 2015, 53(1), pp. 268-300; G.M. Mudacumura, G. Morçöl (eds.), Challenges to Democratic Governance in Developing Countries, Public Administration, Governance and Globalization, Vol. 11, Cham 2014; S. Ozsahin, G. Ucler, The Consequences of Corruption on Inflation in Developing Countries: Evidence From Panel Cointegration and Causality Tests, "Economies" 2017, 5(4), pp. 1-15; L. Tingting et al., op. cit.

8 J.S. Bentzen, How Bad Is Corruption? Cross-country Evidence of the Impact of Corruption on Economic Prosperity, "Review of Development Economics" 2012, 16(1), pp. 164-187; A.R. Menocal, N. Taxell, Why Corruption Matters: Understanding Causes, Effects and How to Address Them: Evidence Paper on Corruption, Department for International Development [UK], January 2015. 
managers report their annual, under-estimated income to their supervisors to keep the difference for their possession. ${ }^{9}$

The third category is facilitation payment which takes the form of a small payment, also called a 'speed' or 'grease' payment or sweetener, it is exchanged to secure or expedite the performance of a routine or necessary action to which a payer has legal or another entitlement for some priorities. Facilitation payment can be considered as financial payment for the purpose of expediting an administrative process. ${ }^{10}$ It is a sweetening payment made to a public or government official as an incentive for the official in return for prioritising some actions or processes expeditiously to the benefit of the party who intentionally offers facilitation payment.

The fourth category of corruption is fraud which is defined as the act of intentionally and dishonestly deceiving someone to gain an unfair or illegal advantage in terms of financial, political or other favours. In other words, a false representation by means of a statement or conduct is made knowingly to gain a material advantage or deceive another so that an individual will act upon it to her/his legal injury. Thus, fraud is intentionally deceiving a person or entity for the sake of monetary or personal gain. ${ }^{11}$

Collusion is seen as another corruptive form. It occurs when there is a secret agreement to perform something dishonest or to trick people. Collusion can be classified as an arrangement between two or more parties collaborating to gain an improper purpose, including exerting an improper influence on the actions of another party. It is relevant to claim that collusion presents a straightforward relationship between bidders in a public procurement, who have the intention to conspire to lift the element of competition from the process. The remarkable mechanism of collusion in public contracts accounts for bid rigging where the bidders have the utmost right to decide among themselves who should 'win' the tender and determine their bids in such a way to assure that the designated bidder is chosen by the purposefully competitive process. Bid rigging is commonly prohibited by

9 N. Sahakyan, K.W. Stiegert, Corruption and Firm Performance, "Eastern European Economics" 2012, 50(6), pp. 5-27; V. Alfano, S. Capasso, R.K. Goel, op. cit.

10 B. Clausen, A. Kraay, Z. Nyiri, Corruption and Confidence in Public Institutions: Evidence from a Global Survey, "The World Bank Economic Review" 2011, 25(1), pp. 212-249; P.M. Heywood (ed.), Routledge Handbook of Political Corruption, Routledge 2014; G.M. Mudacumura, Multiple Dimensions of Governance, [in:] G.M. Mudacumura, G. Morçöl (eds.), op. cit.

11 S. Ozsahin, G. Ucler, op. cit.; M.R. Quazi, Corruption and Foreign Direct Investment in East Asia and South Asia: An Econometric Study, "International Journal of Economics and Financial Issues" 2014, 4(2), pp. 231-242. 
the competition law in most legal systems and is considered as a criminal offence in many countries. ${ }^{12}$

The fifth category is extortion, which can be understood as the act of threatening to do something harmful or impairing the extorted party in an indirect or direct way, which could involve even the property of the party, to force the would-be extorted party to accept the harassment requesters. ${ }^{13}$ Simply speaking, under the pressure of extortion, a threat or menace is sent to the extorted party by the receiver to perform a series of harmful actions endangering the extorted party in case the extorted party does not satisfy whatever the receiver wants. So, the extorted party unwillingly does something for the sake of the extorting one.

The last popular denotation of corruption is patronage, clientelism, and nepotism. These are some forms of favouritism in which one party enjoys remarkable support from the superiors with no conditions. In terms of political patronage, it can be the use of state resources to reward individuals for their electoral support. This favouritism can be supplied groups for their assistance with illegal gifts, fraudulently awarded appointments or government contracts by patrons. ${ }^{14}$ As for clientelism, it refers to a complex chain of personal leagues, possibly between political patrons/bosses and their followers/clients, respectively. The alliance can be cemented as mutual, advantageous material bonds in which patrons support directly or indirectly excludable resources (money, jobs or favourable positions) for dependents and accomplices for the purpose of receiving their support and cooperation (votes, attendance at rallies). In this circumstance, the patron gains disproportionate power and has wide latitude about how to bestow the assets within his/her authority. Considering another angle, most patrons are not solitary entities, but are closely linked within a larger net of contacts, mediated by middle men who are in charge of arranging exchanges between the contacts in the mutual networks. ${ }^{15}$ Thus, the concept of clientelism is currently employed to characterise whole political systems in one country. Similarly, nepotism is somehow a notion relating to the patronage. Nepotism is one kind of favouritism in which acquaintances and familiar relationships play a central part in this form. It occurs whereby someone

12 M. Seumas (eds.), Corruption and Anti-Corruption in Policing - Philosophical and Ethical Issues, Springer 2016; L. Tingting et al., op. cit.

13 F.O. Nwankwo, Impact of Corruption on Economic Growth in Nigeria, "Mediterranean Journal of Social Sciences" 2014, 5(6), pp. 41-46; S. Ozsahin, G. Ucler, op. cit.; A. Belgibayeva, A. Plekhanov, Does Corruption Matter for Sources of Foreign Direct Investment?, "Review of World Economics" 2019, 155(1), pp. 487-510.

14 A.D. Bearfield, What Is Patronage? A Critical Reexamination, "Public Administration Review" 2009, 69(1), pp. 64-76.

15 B. Clausen, A. Kraay, Z. Nyiri, op. cit.; A.R. Menocal, N. Taxell, op. cit. 
in an official position utilises his/her power and authority to create unfair favour or job opportunities for a family member or a friend despite his/her being unqualified or even not meeting the necessary criteria. Nepotism means employing relatives, close friends without meeting any requirements of merits and abilities.

In reality, studies on the understanding of corruption are not new. For the past decades, many scholars, e.g. Asongu ${ }_{1}^{16}$ Bentzen, ${ }^{17}$ Gil-Pareja et al., ${ }^{18}$ Tingting et al., ${ }^{19}$ have investigated different facets of corruption to verify where corruption occurs most frequently and how various groups of the population and the business community express their perspectives on corruption. The government of Vietnam is, especially the Internal Affairs Committee of the Communist Party of Vietnam, in the process of reviewing the implementation of the Anti-corruption Law and the Party's resolution on anti-corruption which was passed in 2006 to submit to the National Assembly an amendment to the current anti-corruption law to meet the demand of the present situation. Although the Government Inspectorate (GI) and the Office of the Steering Committee on Anti-corruption (OSCAC) have issued stricter directives to combat corruption and reduce its consequences, corruption still poses an important, challenging obstacle for Vietnam's development. The authoritative instructions of governmental activities to reinvigorate the fight against corruption have been in effect. The present study contributes an important and novel investigation to understand corruption in a developing country under citizens' perspective on corruption, so it provides insight understanding what aspects of anti-corruption policies and institutions prove to be effective and ineffective. Otherwise, the outcomes verify not only areas of public concerns where reforms are more feasible to meet resistance from within the bureaucracy, but also sectors which require paying attention to. The citizens' viewpoints highlight what aspects of public administration are most complied with integrity and, conversely, exposed their corruptive state or other measures of poor performance. Thus, an understanding of citizens' perception on corruption plays an essential role in identifying what needs to reform the anti-corruptive laws. This study basically addresses the following questions:

1. What do Vietnamese citizens currently think about the corruptive situation?

2. How effective do they perceive the preventive measures against corruption?

\footnotetext{
16 A.S. Asongu, Globalization, (Fighting) Corruption and Development: How Are These Phenomena Linearly and Nonlinearly Related in Wealth Effects?, "Munich Personal RePEc Archive" 2012, pp. 1-31, https://mpra. ub.uni-muenchen.de/id/eprint/36899 (access: 17.06.2021).

17 J.S. Bentzen, op. cit.

18 S. Gil-Pareja, R. Llorca-Vivero, J.A. Martínez-Serrano, op. cit.

19 L. Tingting et al., op. cit.
} 


\section{Literature Review}

There has been a great, growing amount of literature on corruption reflecting the complexity, multidimensionality and importance of the issue, drawing the attention of many countries worldwide. Despite the broad controversies over the challenges or consequences of corruption, the literature review investigates three dimensions which centralise the theoretical framework.

\section{Factors Facilitating Corruption}

Corruption is a complex and multi-faceted phenomenon characterised by a range of economic, political, administrative, social and cultural factors with both domestic and international scales. When considering the economic factor, it has been examined by numerous researchers (i.e. Sahakyan and Stiegert, ${ }^{20} \mathrm{Quazi},{ }^{21}$ Bayar and Alakbarov, ${ }^{22}$ Gil-Pareja et al., ${ }^{23}$ Belgibayeva and Plekhanov, ${ }^{24} \mathrm{Nwankwo}^{25}$ to clarify how corruption affects the economic development of a country. Sahakyan and Stiegert ${ }^{26}$ conduct a survey from over 400 Armenian businesses to investigate the perceived favourability and impact of corruption on firm-level performance to prove how different firm scales view corruption as favourable. Their finding proposes that no matter how old, young, large and profitable companies are, they still prefer seeing corruption as favourable on firm performance. This study, however, does not mention the consequences of firm-preferred corruption on the socio-economy or political policing systems. Similarly, Gil-Pareja et al. ${ }^{27}$ review gravity equations basing on the last econometric advances on a wide sample of countries and years, using three different measures of corruption, such as perception-based indexes and indicators of corruption across countries on international trade. They provide an ambiguous conclusion, i.e. although corruption is considered as a barrier to trade by lifting the cost of doing international business, it sweetens trade in countries with strict regulations. In their study, they utilise

\footnotetext{
20 N. Sahakyan, K.W. Stiegert, op. cit.

21 M.R. Quazi, op. cit.

22 Y. Bayar, N. Alakbarov, Corruption and Foreign Direct Investment Inflows in Emerging Market Economies, "Ecoforum" 2016, 5(2), pp. 303-308, http://www.ecoforumjournal.ro/index.php/eco/article/view/431 (access: 17.06.2021).

23 S. Gil-Pareja, R. Llorca-Vivero, J.A. Martínez-Serrano, op. cit.

24 A. Belgibayeva, A. Plekhanov, op. cit.

25 F.O. Nwankwo, op. cit.

26 N. Sahakyan, K.W. Stiegert, op. cit.

27 S. Gil-Pareja, R. Llorca-Vivero, J.A. Martínez-Serrano, op. cit.
} 
second sources, not primary ones. Consequently, their findings might not be dependable because the results are greatly based on other research outcomes. Nwankwo ${ }^{28}$ analyses the relationship between the gross domestic product (GDP) and corruption index in Nigerian economy relating to the impact of corruption. He concludes that the level of corruption has a significantly negative impact on economic growth in Nigeria over the past years. He also claims that Nigerian economy could not grow fast if there is no sight of corruption. Accordingly, he states that corruption has advantages and disadvantages to a certain extent. In his research, the result is drawn from second sources; he does not examine the citizens' perceptions of the corruptive consequences. Regarding Foreign Direct Investment (FDI), the influence of corruption on FDI inflows is conducted by Quazi $^{29}$ in East Asia and South Asia. By synthesising and analysing the Generalized Least Squares approach with 1995-2011 panel data, the study confirms that FDI is negatively and robustly affected by corruption, and strongly demands devising pro-FDI strategies to give favourable, transparent, and appealing environments to call for more FDI inflows. This research is also unconcerned about citizens' perceptions of corruption. Inversely, Bayar and Alakbarov ${ }^{30}$ investigate the connection between corruption and FDI inflows in 23 emerging market economies during the timeframe of 2002-2014, exploiting the cointegration test to highlight the control of corruption as well as rule of law. As a result, they claim that control of corruption and rule of law have no statistically significant impact on FDI inflows in overall panel. However, their findings in certain circumstances yield the different outcomes, particularly the control of corruption and rule of law have a negative or positive impact on FDI inflows in each case - herein a country. Belgibayeva and Plekhanov ${ }^{31}$ do a cross-country empirical analysis of the impact of corruption on FDI flows, focusing on the interaction between control of corruption in the source and destination countries. The study asserts that FDI inflows become higher if one country improves its preventive measures against corruption, i.e. stronger cross-border investments as long as less corruptive environments. These aforementioned studies in terms of FDI inflows share similarities in that they pay no attention to the citizens' perceptions of corruption.

The political factor has somehow greatly affected corruption. Actually, political consequences are dependent on how a country is ruled by its governmental actions. For instance, a weak government, with its ruling elite exercises, has little control

\footnotetext{
28 F.O. Nwankwo, op. cit.

29 M.R. Quazi, op. cit.

30 Y. Bayar, N. Alakbarov, op. cit.

31 A. Belgibayeva, A. Plekhanov, op. cit.
} 
or supervision of corruptive prevention, its legitimacy might be decayed, so corruption is increased as such. In other ways, uncontrolled or unrestricted corruption leads to the general effect of undermining one country and its political legitimacy. ${ }^{32}$ Therefore, a strong state leadership implements straightforward and drastic anti-corruptive activities to put the corruption under control, assuring the level of corruption at a stable, predictable and acceptable level for businesses and general public. Sanchez ${ }^{33}$ confirms that the legitimacy and efficiency of the state, i.e. the general attitude towards corruption, is heavily affected by the overall esteem of the rule system in the eyes of the population. Thus, corruption is regarded as a coercive practice that is not rooted in material transactions, but legal authority is exploited in the pursuit of multifarious forms of power. Clearly, citizens express their opinions on a strong political system as a benevolent authority. Thus, legitimacy is generally dependent on the services supported and the ability to meet the popular demands, more than the efficiency of the state apparatus and its operations. Sanchez's finding only assesses the services of the state operation to meet the needs of its people.

Mudacumura $^{34}$ discusses multiple dimensions of governance in developing countries to demonstrate that good governance is viewed as a key element of development, and it is decisive in the success of development commonly equated to democratic governance which, as a paradigm, activates the role of passive citizens to active participants in democracy. He also asserts the concept of democracy as a regime or a system of government in which rulers take responsibility for their actions in the public domain by citizens acting indirectly through the competition and cooperation of their representatives. This study investigates six dimensions, namely structure, politics, administration, economy, society, and spirits. Nevertheless, these dimensions cover only the definitions in general, without further detailed discussion on the nature of each dimension. For the cultural factor, Sylla ${ }^{35}$ analyses the phenomenon of corruption in the cultural context of sub-Saharan Africa on the basis of two alternative frameworks, namely the sociological, and social capital theories, to disclose the factors leading to corruption. The author concludes that corruption in sub-Saharan Africa is caused by various streams, including colonialism, internal structures inherent to Africa itself, Africa's inability

32 B. Clausen, A. Kraay, Z. Nyiri, op. cit.; A.R. Menocal, N. Taxell, op. cit.

33 A. Sanchez, Criminal Entrepreneurship: A Political Economy of Corruption and Organized Crime in India, [in:] P.M. Heywood (ed.), op. cit., pp. 67-76.

34 G.M. Mudacumura, op. cit.

35 K. Sylla, Defining Corruption in the Cultural Context of Sub-Saharan Africa, [in:] G.M. Mudacumura, G. Morçöl (eds.), Challenges to Democratic Governance in Developing Countries, Public Administration, Governance and Globalization, Vol. 11, Cham 2014. 
to reform and mostly the international political economy and the movement of capital. As for this study, it does not exploit primary sources, and most of its conclusion is elicited subjectively from second resources.

\section{Effects of Corruption on the Society}

The effects of corruption have negative impacts on macroeconomic growth, public service delivery, state legitimacy, and stable, favourable business environment. Ravelo $^{36}$ restates Secretary-General Ban Ki-moon's warning message ${ }^{37}$ at the 2012 Economic and Social Council high-level panel on accountability and transparency, who reiterates the importance of combating corruption. He also warns the destruction of the flouring atmosphere of corruption, which possibly undermines macroeconomic development. Ozsahin and Ucler ${ }^{38}$ examine the relationship between corruption and inflation in developing countries and conclude that corruption is blamed for weak economic performance, reducing investments, and resulting in a waste of resources. Otherwise, corruption deteriorates the state apparatus due to the bribery malady which seriously depraves the institutional structure. Owing to the stagnant bureaucratic structure resulted from corruption, economic development is heavily left behind, as not many FDI flows are invested, or even the incentive economic aids have little effect on boosting their economic growths owning to corruptive determinants. Thus, corruption has a negatively effective distribution to the financial and public resources, productivity, and economic performance. Additionally, Olken and Pande ${ }^{39}$ carry out a study on the corruption in developing countries to measure the relationship between the corruption and economic growth in terms of the standard economic incentive theory under the supervision of anti-corruption policies. Their results disclose that the microeconomic sectors are seriously affected as the effects of anti-corruption policies which become attenuated due to officials employing alternative strategies to pursue tents. This study exploits the secondary sources, i.e. using the earlier results to compare, synchronise, and produce final results. Besides, it does not investigate how citizens perceive the effectiveness of anti-corruption policies impacting on microeconomic

\footnotetext{
36 L.J. Ravelo, 30 Percent of Aid Lost to Corruption - Ban Ki-moon, "The Development Newswire" [blog] 10.07.2012, www.devex.com/news/30-percent-of-aid-lost-to-corruption-ban-ki-moon-78643 (access: 17.06.2021).

37 Ibidem.

38 S. Ozsahin, G. Ucler, op. cit.

39 A.B. Olken, R. Pande, Corruption in Developing Countries, "Annual Review of Economics" 2012, 4(1), pp. 479-509.
} 
development in developing countries. Bentzen ${ }^{40}$ estimates the causal impact of corruption on gross domestic product per capita across the countries. She accumulates, compares, and analyses the econometric shortcomings of the literature relating to six components, namely GDP per capita, corruption, remaining institutions, geography, Hofstede culture measures, and remaining culture. The results show that corruption strongly exerts a significant and negative impact on countries' productivity levels. Yet, her study only exploits all measures from an online dataset, which reduces the liability of the research findings.

As for corruption badly influencing public service delivery, Uslaner ${ }^{41}$ overviews this problem in many countries worldwide and concludes that corruption leads to the loss of trust in public services. That is, people in countries with a high level of corruption recognise a clear connection between malfeasance by their officials and inequality. Besides, corruption reduces not only the total level of public investment, but also the quality if services procure as well. He especially notes the acute problem in infrastructure and construction projects, where lower-quality inputs or technical expertise are substituted for the higher-value inputs that the original contract provided for. Furthermore, the effects of corruption in public service delivery are accounted for gender-specific effects, where women are treated unfairly and are especially vulnerable to shortfalls in public service provision. Consequently, men and women do not share a common bond with each other; social-welfare policies are also negatively influenced by gender discrimination, which calls for more equality in public service delivery. This study exploits secondary resources for eliciting the outcomes and it does not specifically mention the sources of documents which contribute to the findings. Richey ${ }^{42}$ conducts research on the impact of governmental corruption on generalised social trust to uncover how institutional actions influence generalised trust in the United States. In his descriptive, comparative study, he tests the impact of governmental corruption with an aggregate state-level measure of corruption combined with the American National Election Studies panel data for the successive time period. The result reveals that governmental corruption makes the society feel untrustworthy. In addition, citizens blame politicians' untrustworthy behaviours for the causes of why people have low attitudes towards more effective law enforcement. The author suggests increasing trust and governmental efficiency with clean government programmes. His research is based on the cross-sectional study exploiting the secondary sources to bear the results.

\footnotetext{
40 J.S. Bentzen, op. cit.

41 E.M. Uslaner, The Consequences of Corruption, [in:] P.M. Heywood (ed.), op. cit., pp. 199-211.

42 S. Richey, The Impact of Corruption on Social Trust, "American Politics Research" 2010, 38(4), pp. 676-690.
} 
Dahlström ${ }^{43}$ discusses the relationship between bureaucracy and corruption, specifically grand and petty corruption to highlight state legitimacy. He defines grand corruption as misuse of public office on the higher levels within the state and he claims that a well-structured and efficient public administration is a fundamental attribute of civilised society and is crucial for the state-building process, which influences prosperity over the centuries, whereas petty corruption refers to the low-level government bureaucrats, i.e. the involvement of administrators and not politicians. This research concludes that employment and pay affect administrators' norms and deter them from corruption and their incentives to take bribes and accept other kickbacks in a way that prevents petty corruption but leaves grand corruption untouched. Similarly, Ivanyna ${ }^{44}$ conduct a qualitative analysis on the macroeconomics of corruption relating governance and growth to discriminate between petty and grand corruption. They state that petty corruption means bribing bureaucrats who take responsibility for implementing and enforcing laws and regulations under the circumstance that bribes could deteriorate the counter-productive laws and regulations. Meanwhile, grand corruption involves high-level politicians who are in charge of setting the country's economic policy. Once politicians are unavoidable to commit grand corruption, fiscal crises might be flourished and more feasible to undermine an economic growth. Therefore, state legitimacy is heavily settled by the petty and grand corruption. Maruichi and $\mathrm{Abe}^{45}$ undertake an empirical study to investigate the relationships between the overall business environment and business obstacles in Vietnam to provide the reference for the stable, favourable business environment under the impact of corruption. They discover that the more severe the obstacles, the fewer firms are likely to be satisfied with the overall business environment. In their study, they declare to be independent from local authorities while doing the research to assure the liability of the results, as firms seemingly hesitate to express their candid viewpoints on the corruptive states with the officials.

\section{Anti-corruption Measures}

It is subjective to claim from ongoing anticorruption work that the context, stakeholders, and the specific nature of corrupt behaviours might be settled by multiple,

\footnotetext{
43 C. Dahlström, Bureaucracy and Corruption, [in:] P.M. Heywood (ed.), op. cit., pp. 110-120.

44 M. Ivanyna, A. Mourmouras, P. Rangazas, The Macroeconomics of Corruption. Governance and Growth, "Springer Texts Business, Economics" 2018, 1(1).

45 D. Maruichi, M. Abe, Corruption and the Business Environment in Vietnam: Implications from an Empirical Study, "Asia and the Pacific Policy Studies" 2019, 6(2), pp. 222-245.
} 
different interventions. In other words, not all types of corruption share the similarities. Anti-corruption measures could be considered under the following dimensions, such as public financial management, supreme audit institutions, direct anti-corruption interventions and social accountability initiatives.

Manacorda ${ }^{46}$ reports the results of a two-year international research project conducted for the United Nations Office on Drugs and Crime (UNDOC) to offer solutions for reducing bribery and corruption in corporations and institutions. The book is illustrated with some studies mentioning guidelines for the adoption of compliance programmes developed by international institutions to serve as models for the future. The principal result of the book is a three-pronged Anti-Bribery Corruption Model (a so-called ABC Model), endorsed by the United Nations, intended as a corruption prevention tool adopted by private corporations. Schoor ${ }^{47}$ conducts a multiple-case study and provides the findings of six success factors for sector-specific Coordinated Governance Initiatives, namely the initiatives' company composition, situations of crisis and external threats as initiating factors, the existence of a supportive institutional framework, the continuing commitment of participants, the complexity-dependent governance structures and procedures, and effective enforcement mechanisms for reputation protection. The author concludes that combating corruption requires a global perspective and collective efforts of both governments and private actors.

\section{Methods}

\section{Research Design}

The research was basically designed to investigate from a cross-section of Vietnamese citizens' current perception of the level corruption to propose some initiatives for combating corruption locally and globally. 385 participants were randomly chosen as a sample population, utilising the stratified random sampling method based on Cochran's formula. This was because of the impossibility for the researcher, within the constraints of time and money, to collect the Vietnamese citizens' opinions. The questionnaire, with a supporting letter from the local government, was sent with a prepared envelope. The participants were requested to return the

46 S. Manacorda, F. Centonze, G. Forti, Preventing Corporate Corruption: The Anti-Bribery Compliance Model, Springer 2014.

47 V.B. Schoor, Fighting Corruption Collectively: How Successful Are Sector-Specific Coordinated Governance Initiatives in Curbing Corruption?, Wiesbaden 2017. 
questionnaire within one month. The letter from the researcher attached to the questionnaire explained the objectives and relevance of the study, assured their anonymity, and gave them the choice of not participating in the study if did they not want to. A contact number was also available for a quick response, and in case of a low response rate (less than 20\%), a courtesy reminder was sent to respondents. Fortunately, this study was well received by the respondents.

\section{Sample Population}

The participants were randomly chosen via the stratified random sampling method to investigate Vietnamese citizens' perception of the corruptive problems. As for the unknown sample population, Cochran's formula was employed to determine the number of 385 participants. Particularly, 196 male participants (50.9\%) together with 189 female respondents (49.1\%) partook in this study. The research also concerned their working positions, so the results revealed that 46 participants, equivalent to $11.9 \%$, worked as state officials. 40 people (10.4\%) were freelancers, 12 were NGO employees (3.1\%). 17 students (4.4\%) expressed their stances, 21 workers $(5.5 \%)$ took part in the survey, 71 civil servants $(18.4 \%)$ returned their responses, 33 educators $(8.6 \%)$ represented a part of the total sample population, 22 farmers/ peasants $(5.7 \%)$ were available for the research, 40 business people accounted for $10.4 \%$ of all respondents, and the majority of respondents, namely 77 participants $(20.0 \%)$, refused to reveal their careers. Additionally, the smallest number of the participants, i.e. 17 (4.4\%), involved people aged 20+. There were 107 people aged $30+(27.8 \%$ of all the respondents). 104 respondents $(27 \%)$ were aged $40+, 82$ participants (21.3\%) were over 50 years old, and 75 citizens (19.5\%) were over 60 years old. As regards the participants' educational levels, 47 respondents accounting for $12.2 \%$ had general education, 49 people $(12.7 \%)$ received vocational training degrees, 140 respondents (36.4\%) gained tertiary diplomas, remarkably 58 citizens (15.1\%) held post-graduate degrees, and 91 participants (23.65) preferred not to disclose their academic level. When investigating the frequency of mass media access, the majority of the participants, particularly 303 people $(78.7 \%)$, stated that they accessed mass media every day, whereas the rest of them, 82 respondents $(21.3 \%)$ reported that they did not have definite time using the mass media.

\section{Research Instrument}

The study exploited the researcher-made questionnaire, which was constructed on the basis of factual and behavioural criteria recommended by Dornyei and 
Taguchi. ${ }^{48}$ The questionnaire was designed, then sent to 4 experts on law and politics for content validation. After that, it was fine-tuned with a group of 50 volunteer participants in a dry run to validate the strengths and weaknesses of the instrument. The results of the pilot experiment for validity of the questionnaire were selected when meeting Alpha values ( $\alpha=0.84-0.90$, reliable). ${ }^{49}$ The final version was again sent back to 4 experts to examine and validate the liability.

\section{Statistical Tools}

The study used the summated rating scale, commonly referred to as the Likert scale, had equal attitudinal value. Thus, the quantitative data was analysed using descriptive statistics. Specifically, frequency count and percentage were employed to analyse the demographic information, and the present, major causes of corruption. A descriptive mean was used to reflect an attitude towards the issue in question, particularly the current issues that the country faced, the governmental actions, the seriousness of the problems, the effectiveness and activeness of public institutions, the professionals/persons' involvement, the extent of corruption, the effectiveness of institutions/individuals in combatting corruption, the effective measures in combatting corruption, the punishment consequences of corruption, and the feasibility of corruptive prevention in the future.

\section{Results and Discussion}

When investigating the serious proportions of corruptive problems facing community and the country as a whole, the participants viewed the opinions that inflation $(M=3.55 ; S D=.683 \%)$, drug trafficking $(M=3.53 ; S D=.696 \%)$, and polluted environment $(M=3.76 ; S D=.600 \%)$ negatively affected their lives. These results prove that in the developing countries inflation has a far-reaching consequence which may affect social crimes or polluted environment. Actually, the higher corruption occurs, the more serious the inflation takes place, so putting corruption under control with effective policies and enforced laws can help reduce the inflation rate and achieve price stability. ${ }^{50}$ Similarly, the participants had moderate viewpoints on high costs of living $(M=4.24 ; S D=.648 \%)$, housing $(M=3.31$; $S D=.643 \%)$, unemployment rate $(M=3.31 ; S D=.795 \%)$, safety concerns/crime

48 Z. Dornyei, T. Taguchi, Questionnaires in Second Language Research: Construction, Administration and Processing, 2nd ed., New York 2010.

49 L.J. Cronbach, Coefficient Alpha and the Internal Structure of Tests, "Psychometrika" 1951, 16, pp. 297-334.

50 S. Ozsahin, G. Ucler, op. cit. 
$(M=3.22 ; S D=.675 \%)$, drug abuse $(M=3.17 ; S D=.680 \%)$, and bad leadership $(M=3.11 ; S D=.716 \%)$. In addition, they believed that corruption in public services $(M=3.31 ; S D=.758)$ and private sectors $(M=3.31 ; S D=.758 \%)$ occurred moderately. In the same situation, they indicated the moderate extent in education services $(M=3.19 ; S D=.612 \%)$, healthcare services $(M=3.19 ; S D=.611 \%)$, police harassment $(M=3.15 ; S D=6.12 \%)$, unfair judicial system $(M=3.14 ; S D=.587 \%)$, and socio-economic inequalities $(M=3.36$; $S D=.618 \%)$. These figures denote that although the inflation rate is serious, the government has done best to keep everything in order. It is unavoidable to declare one country free from corruption, especially in developing countries such as Vietnam. The data shows the fact that corruption has been at acceptable expectations of the citizens accordingly. Besides, the results show that the participants consider the following problems as not very serious, particularly access to clean water $(M=2.54 ; S D=.732 \%)$, food availability/ poverty $(M=2.57 ; S D=.768 \%)$, roads in poor condition $(M=2.54 ; S D=.676 \%)$, social welfare $(M=2.52 ; S D=.689 \%)$, epidemic diseases $(M=2.45 ; S D=.562 \%)$, and HIV/AIDS $(M=2.35 ; S D=.549 \%)$. Overall, the standard deviation percentage was below 1.0, which proved that there was a slight difference in the respondents' choices. Noticeably, people perceive the basic needs are met in the country. Some studies ${ }^{51}$ have evaluated that the basic needs have seriously been affected and frequently ignored by the governmental policies. In general, the problems perceived by Vietnamese citizens are somewhat similar to the data provided by the United Nations Development Programme (UNDP) (2020), ${ }^{52}$ which lists Vietnam in the group of high human development, ranked 117th over 189 countries in the order.

To evaluate how effectively the government dealt with the aforementioned issues, the respondents were requested to express their opinions. The results revealed that the participants thought the government did excellently to solve the food availability/poverty $(M=4.48 ; S D=.692 \%)$. The respondents also reported that the government did well in tackling the following problems, such as shortage of housing $(M=3.64 ; S D=.609 \%)$, socio-economic inequalities $(M=3.77 ; S D=.692 \%)$, social welfare $(M=3.64 ; S D=.805 \%)$, epidemic diseases $(M=3.71 ; S D=.749 \%)$, HIV/ AIDS $(M=3.82 ; S D=.635 \%)$, access to clean water $(M=3.96 ; S D=.587 \%)$, and roads in poor condition $(M=3.82 ; S D=.577 \%)$. They had neutral opinions when it came to evaluating the following governmental solutions, namely high costs of living $(M=3.56 ; S D=.712 \%)$, unemployment rate $(M=3.33 ; S D=.683 \%)$, safety

51 I.e. T. Murray, op. cit.; S. Ozsahin, G. Ucler, op. cit.; G.M. Mudacumura, op. cit.

52 Human Development Report 2020, The Next Frontier Human Development and the Anthropocene, The United Nations Development Programme (UNDP), http://hdr.undp.org/sites/default/files/hdr2020.pdf (access: 17.06.2021). 
concerns/crime $(M=3.10 ; S D=.514 \%)$, drug abuse $(M=2.92 ; S D=.819 \%)$, and bad leadership $(M=3.02 ; S D=.475 \%)$. On the same side, they had average viewpoints when evaluating these problems, particularly corruption in public services $(M=3.09 ; S D=.579 \%)$, corruption in private sectors $(M=3.21 ; S D=.611 \%)$, education services $(M=3.24 ; S D=.604 \%)$, healthcare services $(M=3.32 ; S D=.620 \%)$, police harassment $(M=3.05 ; S D=.685)$, and unfair judicial system $(M=3.02$; $S D=.573 \%)$. Noticeably, they did not think that the governmental actions were good enough to address these issues, namely the inflation rate $(M=2.19 ; S D=.579)$, drug trafficking $(M=2.48 ; S D=.835 \%)$, and polluted environment $(M=2.22$; $S D=.703 \%)$. The participants made a similar assessment according to the report of nowcast of the global poverty rate of the World Bank (WB). ${ }^{53}$ With the effective governmental policies, the poverty rate in Vietnam was reduced from $20.7 \%$ in 2010 to $6.7 \%$ in 2018. Another equivalent index was about the polluted environment, people partaking in the survey had similar opinions towards the data reported by $\mathrm{WB}$ as the $\mathrm{CO}_{2}$ emission rate increased from 1.623 in 2010 to 2.058 in $2016 .{ }^{54} \mathrm{In}$ reality, the Vietnam government has practised so many initiatives to eliminate drug trafficking and the country has been making significant efforts to update its legal framework to better combat transnational organised criminal networks and officials complicit in trafficking offences. For other factors, the participants did not indicate their specific stance on those determinants.

On considering the major present causes of corruption in the country, the majority of the respondents did not blame it on poverty $(n=305 ; 79.2 \%)$, they thought it was partly true $(\mathrm{n}=43 ; 11.2 \%)$, and they accused poverty of corruptive causes $(n=43 ; 11.2 \%)$. According to the previous data by the WB, the number of people experiencing poverty in Vietnam is very low $(6.7 \%)$, which explains why the participants did not consider poverty as one major cause of corruption. Another factor was greed/selfishness. Almost all participants considered this as true $(n=274$; $71.2 \%)$, they believed it was partially true $(n=61 ; 15.8 \%)$, and they did not see this cause as acceptable $(n=50 ; 13.0 \%)$. In this aspect, the respondents supposed that corruption belonged to the ethical virtues, and they saw it unacceptable to approve the moral wrongdoing of the corruptive delinquents. Actually, law and morality are completely different in that laws have properties which moral principles and values do not certainly possess. Put more simply, laws must have certain institutional properties not necessarily possessed by moral principles and values, i.e. laws

53 Poverty headcount ratio at national poverty lines (\% of population) - Vietnam: https://data.worldbank. org/indicator/SI.POV.NAHC?locations=VN (access: 17.06.2021).

$54 \mathrm{CO}_{2}$ emissions (metric tons per capita) - Vietnam: https://data.worldbank.org/indicator/EN.ATM.CO2E. $P C$ ?end $=2016 \&$ locations $=V N \&$ start $=1960 \&$ view $=$ chart $($ access: 17.06 .2021$)$. 
are enacted by some institutional authorities in accordance with some valid institutional process. ${ }^{55}$ Regarding the high costs of living factor, most people accepted it to be partially true $(n=293 ; 76.1 \%)$, while 53 participants $(13.8 \%)$ admitted this cause, and the rest did not believe that $(n=39 ; 10.1 \%)$. According to the International Living magazine ${ }^{56}$ - a monthly publication for subscribers detailing the best places in the world to live, retire, travel, and invest, founded in 1979 by Bill Bonner, having offices and writers located all over the world, it remarks that Vietnam is an inexpensive country, less than half in terms of the costs of living compared with that in the West, and anywhere, from $5 \%$ to $25 \%$ with that in many other Southeast Asian countries. It is surprising to know that most participants chose the high costs of living as the major cause of corruption. In regard to poor remuneration/payment, most of them $(n=274 ; 71.2 \%)$ acknowledged that it was partially true to blame this factor for the cause of corruption, 73 respondents (19\%) conceded it was true, whereas a small number of people rejected this factor as the cause of corruption $(n=38 ; 9.9 \%)$. As one glimpses at the data, it is logical to acknowledge that poor remuneration/payment commonly leads to corruption. When the basic needs are not satisfied, people frequently find out means of earning money to meet their living demands. ${ }^{57}$ As far as the problem of lack of the control and accountability of public officials is concerned, 285 respondents (74\%) acknowledged that it was partially true, many of them thought that this factor contributed to the causes of corruption $(n=70 ; 18.2 \%)$, and several participants refuted this factor $(n=30 ; 7.8 \%)$. In this regard, transparency plays an important role in good government which requires any governmental and nongovernmental institutions involved in the delivery of public services to be transparent, and their behaviours and motives to be readily knowable when in need. As for improving the accountability of public officials, it is necessary for local governmental organisations and international funding agencies to have access to required information, meet relevant inquiries and even provide unsolicited information. ${ }^{58}$ Considering the lack of independent and effective judiciary, it was the same situation as in the case of the previous factors when almost all respondents claimed that it was partially true $(n=312 ; 81 \%)$, the ratios of acceptance and rejection were nearly the same, i.e. 37 participants $(9.6 \%)$ and 36 ones $(9.4 \%)$, respectively. The participants' perceptions in this survey

\footnotetext{
55 M. Seumas (eds.), op. cit.

56 https://internationalliving.com/countries/vietnam/cost-of-living-in-vietnam/ (access: 17.06.2021).

57 A.R. Menocal, N. Taxell, op. cit.; T. Murray, op. cit.

58 G.M. Mudacumura, op. cit.; B. Clausen, A. Kraay, Z. Nyiri, op. cit.
} 
were in line with the assessment of $\mathrm{UNODC}^{59}$ on the existing legal system of Vietnam on anti-corruption which is extensive, and broadly compatible with the mandatory requirements set by the United Nations Convention against Corruption (UNCAC). For moral indecency, the majority of the respondents believed to be partially relevant to accuse this factor as the cause $(n=287 ; 74.5 \%)$, following this rank was the acceptance of the fact $(n=67 ; 17.4 \%)$, and the smallest population did not approve of this factor $(n=31 ; 8.1 \%)$. Thus, it is easy to realise that corruption reduces social trust, especially governmental corruption may make the society seem untrustworthy. In reality, the untrustworthy behaviour of politicians results in the deficiency of governmental influence on building up people's trust on anti-corruption movements. ${ }^{60}$ Regarding poor government leadership, the majority of the respondents blamed this aspect for the cause of corruption $(n=311 ; 80.8 \%)$, meanwhile, 50 respondents (13\%) approved this cause, but 24 participants $(6.2 \%)$ did not see it as true. It can be said that good governance is regarded as commonplace as a key element of development. It determines the success of development and is often equated to democratic governance. Good governance as a paradigm turns the role of citizens from passive to active participants in democracy. As a matter of fact, good governance includes many characteristics such as an efficient public service; an independent judicial system and legal framework to enforce contracts; the accountable administration of public funds; an independent public auditor, responsible to a representative legislature; respect for the law and human rights at all levels of government; a pluralistic institutional structure; and a free press. In short, good governance could be comprised of transparency, responsiveness, and accountability ${ }^{61}$ When examining whether it was lack of effective corruption reporting system, the results presented that 280 participants considered this perspective to be partially true, only 73 ones (19\%) accepted it to be true, whereas 32 respondents $(8.3 \%)$ disapproved of this statement. This refers to the governmental transparency law and access to knowable information. As for the characteristics of good governance mentioned above, transparency law is one of the core elements of democratic governance. ${ }^{62}$ The access to information relates to the freedom of information, which is thought to have power to 'clean up' government. Thus, the information revolution has effectively eliminated many costs associated

59 https://www.unodc.org/southeastasiaandpacific/en/what-we-do/anti-corruption/topics/2020/advancing-judicial-fight-against-corruption-viet-nam.html (access: 17.06.2021).

60 S. Richey, op. cit.

61 G.M. Mudacumura, op. cit.; B. Hindess, Good Government and Corruption, [in:] P. Larmour, N. Wolanin (eds.), Corruption and Anti-corruption, Canberra 2013; D. Hough, Corruption, Anti-Corruption and Governance, [in:] P.M. Heywood, D. Hough (eds.), Political Corruption and Governance, Palgrave-Macmillan 2013.

62 D. Hough, op. cit. 
with obtaining, storing, processing and diffusing information, bringing swifter access to larger amounts of data than ever before. Transparency and freedom of information are also seen as a means to empower citizens and as a lever to access social and economic rights, particularly in the developing world. ${ }^{63}$ To investigate the possibility of poor law enforcement/punishment of the corrupt, most of the participants agreed on this fact $(n=225 ; 58.4 \%) .120$ ones $(31.2 \%)$ stated that it was partially true, and the minority of them $(n=40 ; 10.4 \%)$ protested against this cause. Judging from the data, it can be concluded that the present punishment should be revised and adjusted for the tendency to enforce corruptive law in order to curb corruption. The last feature in this survey to find out if corruption gave better services, most of the participants $(n=267 ; 69.4 \%)$ denied this hypothesis, while 62 participants $(16.1 \%)$ considered it to be partially true, and 56 ones (14.5\%) accepted it to be the cause of corruption. In the research conducted by Gil-Pareja et al., ${ }^{64}$ the findings figured out the fact that corrupt agents may facilitate trade in countries with strict regulations. In contrast, the respondents in this study protested the possibility of better services under the condition of corruption.

The study exploited the citizens' perceptions towards public institutions involving corruption. They confessed not to know the corruptive state in the immigration department $(M=1.41 ; S D=.678 \%)$, and court $(M=1.38 ; S D=.689 \%)$. They also noted that some public institutions were not experiencing corruption, such as education institutions $(M=2.08 ; S D=.478 \%)$, the People's Procuracy of Vietnam $(M=2.04 ; S D=.539 \%)$, banking $(M=2.09 ; S D=.549 \%)$, and Vietnam state treasury $(M=2.08 ; S D=.632 \%)$. Furthermore, they evaluated some public institutions, to a certain extent, as involving corruption, namely public service board $(M=3.06$; $S D=.682 \%)$, healthcare institutions $(M=3.03 ; S D=.502 \%)$, traffic police $(M=3.01$; $S D=.448 \%)$, and social welfare body $(M=3.07 ; S D=.485 \%)$. In general, the participants made a close choice by looking at the standard deviation values which were all under $1 \%$, denoting the similarity among their choices. The data shows that some public institutions seem to be alien to the citizens, people do not know much about their activities, which is due to lack of transparency. As for governance transparency, it is one of the criteria which good governance may include in itself. Judging from the data, high governmental institutions do not involve in corruption, which is very essential in preventing and combating corruption. ${ }^{65}$

As far as studying of who was involved in corruption was concerned, the participants confirmed that political party leaders $(M=2.13$; $S D=.499 \%)$, and lawyers

\footnotetext{
63 B. Worthy, T. McClean, Freedom of Information and Corruption, [in:] P.M. Heywood (ed.), op. cit.

64 S. Gil-Pareja, R. Llorca-Vivero, J.A. Martínez-Serrano, op. cit.

65 C. Dahlström, op. cit.; M. Ivanyna, A. Mourmouras, P. Rangazas, op. cit.; V.B. Schoor, op. cit.
} 
$(M=2.21 ; S D=.601 \%)$ were not corruptive. They had no idea about whether any professionals might be involved in corruption, specifically the People's Procuracy of Vietnam $(M=1.37 ; S D=.624 \%)$, judges $(M=1.58 ; S D=8.66 \%)$, court clerks $(M=1.56 ; S D=8.99 \%)$, magistrates $(M=1.38 ; S D=8.23 \%)$, officials of the corruption prevention and combating bureau $(M=1.63$; $S D=.581 \%)$, and officials of non-governmental organisations (NGOs) $(M=2.14$; $S D=.799 \%)$. Surprisingly, some professionals were rated as slightly involved in corruption, particularly ministers $(M=2.84 ; S D=.789 \%)$, members of parliament $(M=3.12 ; S D=.689 \%)$, officials of social organisations $(M=3.19 ; S D=.626 \%)$, doctors and nurses $(M=3.04$; $S D=.745 \%)$, educators $(M=3.32 ; S D=.658 \%)$, police officers $(M=3.12 ; S D=.723 \%)$, revenue/customs officials $(M=3.08 ; S D=.756 \%)$, and journalists $(M=3.16$; $S D=.792 \%)$. Remarkably, the respondents supposed that most of business people were involved in corruption $(M=3.75 ; S D=.704 \%)$. Thus, they made nearly the same choices by seeing the standard deviations under $1 \%$. In general, citizens have a good impression of political party leaders. With the strong determination in curbing corruption, the party's General Secretary, Trong, ${ }^{66}$ affirms that anti-corruption will continue, though it is a long and arduous fight because there is no 'no-go zone', 'exception' in the anti-corruption campaign. However, there are many professionals who are mysterious or reserved to the public in the fight for anti-corruption. The previous data has something in common with the respondents' following assessment of their effectiveness in preventing and combatting corruption. On assessing the institutions/individuals that were effective or helpful in preventing and combating corruption, the participants showed their perceptions that both political party leaders $(M=4.40 ; S D=.501 \%)$ and members of parliament $(M=4.35 ; S D=.735 \%)$ were very effective and helpful in fighting against corruption. In addition, other institutions/individuals were considered highly active, effective, and helpful in preventing and combating corruption, particularly the corruption prevention and combating bureau $(M=3.79 ; S D=.750 \%)$, the ministry of public security $(M=4.05 ; S D=.923 \%)$, media (press and TV) $(M=3.59 ; S D=.690 \%)$, non-government organisations $(M=3.85 ; S D=.941 \%)$, political party member $(M=3.62 ; S D=.724 \%)$, social organisations $(M=3.83 ; S D=.817 \%)$, and the director of the People's Procuracy $(M=3.76 ; S D=.624 \%)$. However, the respondents thought that some institutions/individuals were somehow effective or helpful in this anti-corruption movement, specifically academics and teachers $(M=2.97$; $S D=.746 \%)$, and professional organisations $(M=3.25 ; S D=.777 \%)$. In this sense,

66 http://baochinhphu.vn/Tin-noi-bat/Khong-co-vung-cam-ngoai-le-trong-dau-tranh-phong-chongtham-nhung/416865.vgp (access: 17.06.2021). 
citizens have positive attitudes towards the institutions/individuals when joining hands to combat corruption.

In terms of the extent to which corruption currently took place in the country, the respondents reckoned that it was common to recognise corruption $(M=3.81$; $S D=.689$ ). This assessment seems to be equivalent to the corruption perceptions index by Transparency International ${ }^{67}$ - their mission is to stop corruption and promote transparency, accountability and integrity at all levels and across all sectors of society - which ranked Vietnam as 104th out of 180 countries in 2020.

Evaluating the effectiveness of measures in combating corruption in the country, the participants believed that public education/sensitisation $(M=3.12 ; S D=.548 \%)$, and increasing political will $(M=3.02 ; S D=.549 \%)$ were somehow effective. Moreover, the respondents perceived some measures effective, such as enforcing tough anti-corruption laws $(M=4.05 ; S D=.465 \%)$, improving reporting channels $(M=3.56$; $S D=.648 \%)$, strengthening ethics among public officials $(M=3.73 ; S D=.599 \%)$, eradicating poverty $(M=3.65 ; S D=.688 \%)$, enhancing accountability and transparency $(M=3.69 ; S D=.602 \%)$, improving the salaries of public officials $(M=3.66$; $S D=.690 \%)$, and enhancing good governance $(M=3.54 ; S D=.749 \%)$. The measures of combatting corruption perceived by the respondents are almost effective, but the question might be raised when comparing that effectiveness with the rank in the HDI $2020^{68}$ (117th out of 189 countries) and CPI 2020 (104th out of 180 countries).

On examining the punishment for whoever was accused of corruption or found to be involved in it, the participants totally agreed no applying some forms of punishment, namely prosecution $(M=4.43 ; S D=.712 \%)$, confiscated property $(M=4.51 ; S D=.658 \%)$, and imprisonment $(M=4.35 ; S D=.762 \%)$. When asking them about whether the name of the culprit should be published in all mass media so that the public knew him/her, they had neutral opinions on this perspective $(M=3.12 ; S D=.735 \%)$. Besides, the respondents agreed on the following punishment measures. Specifically speaking, they agreed that if someone was a public official, they would be sacked from service $(M=3.96 ; S D=.553 \%)$, and even convicts might be sentenced to death $(M=3.69 ; S D=.768 \%)$. Another measure was to detain the convicts $(M=3.72$; $S D=.673 \%)$ or they would be given heavy fines $(M=3.98 ; S D=.764 \%)$. The next measure to investigate was that if he/she was a business person, his/her business licence had to be cancelled and his/her name would be posted among the names of those who were not allowed to get a business licence $(M=4.11 ; S D=.746 \%)$. In the event of being a democratically elected leader, he/she had to be removed from his/her position $(M=3.99 ; S D=.743 \%)$. The figures

67 https://www.transparency.org/en/cpi/2020/index/vnm (access: 17.06.2021).

68 Human Development Report 2020... 
reveal that the current punishment forms do not seem to be strict enough, so delinquents do not fear committing a crime. Accordingly, anti-corruption laws should change fiercely to disempower and deter offenders.

When asking about the capability of fighting against corruption in Vietnam for the next decade, the result indicated that it was likely to combat corruption successfully $(M=3.82 ; S D=.906)$. The respondents had a feasible prediction because they believed in the current pathway to combatting corruption since 31 July 2017. Secretary General Nguyen Phu Trong, ${ }^{69}$ head of the Central Anti-corruption Steering Group, said at the 12th Meeting of the Central Steering Committee on the Prevention of Corruption, using a famous slogan, that when the oven heats up, the fresh firewood must also be burned. Since then, the transparent, enforced, governmental actions have been implemented fiercely in curbing corruption.

\section{Conclusion}

With more attention paid to corruption and stricter measures to prevent and combat the issue, people believe that corruption in Vietnam is decreasing, basing on the HDI and CPI figures which constantly decrease, as people closely collaborate in the anti-corruption campaign. The inflation rate, polluted environment, and drug trafficking are highly recognised, which needs enforcing governmental policies to address these problems. The major causes of corruption come from basic needs, not from the ethical governance, as a result of poor law enforcement/punishment of the corrupt. Besides, transparency and information laws should be enacted to be more specific so that people have the right to know, to partake, and to supervise the whole legal process of implementation. The study reveals institutions/ individuals have been effective or helpful in preventing and combatting corruption. The punishments at present are not serious enough, so there is a call for enforcing anti-corruption laws to lower the rate of corruption. Obviously, there is a mismatch between participants' perception in comparison with external assessors, such as HDI or CPI. Although people believe that measures in curbing corruption in the country are effective, the ranks of HDI and CPI are still low, even if these indexes keep changing from low to higher levels. With the current monitoring from the Office of Steering Committee on Anti-corruption, Vietnam hopes to curb corruption to the acceptable rate in the coming decade.

69 Anti-corruption Steering Committee Convenes 12th Meeting, https://vksndtc.gov.vn/tin-tuc/tin-tonghop/phien-hop-thu-12-ban-chi-dao-trung-uong-ve-phong-c-d8-t1918.html?Page=55\# new-related (access: 17.06.2021). 


\section{Implication}

Judging from the above findings, it is necessary to assure the effective implementation of the 2018 Law on Prevention and Control of Corruption, the Law on Access to Information 2016, and its guiding documents, particularly regulations and measures on declaration and disclosure of assets of cadres, and civil servants and controlling conflicts of interest. In addition, the operation of the state apparatus should be re-examined to identify and put forward specific, preventive measures to address each kind of corruption, including state capture, which represents a dangerous form of corruption. For this type of corruption, there exists a close tie between high-ranking officials and businesses with great political and economic power to orient and steer public policies for profit. Furthermore, it is advisable to promote institutional reform and strengthen the operation of the state apparatus in the direction of open governance to effectively encourage the role of non-state actors, such as social organisations, enterprises, newspapers. and people in the fight against corruption, together with promoting the application of information technology to curb corruption. More importantly, cooperation with international organisations, such as the WB, UNDP, TI, to exchange experiences in renovating and reforming the ways to address corruption successfully should also be involved.

\section{Bibliography}

Alfano V., Capasso S., Goel R.K., EU accession: A Boon or Bane for Corruption?, "Journal of Economics and Finance" 2020, 45(1), pp. 1-21, https://doi.org/10.1007/s12197020-09522-8.

Asongu A.S., Globalization, (Fighting) Corruption and Development: How Are These Phenomena Linearly and Nonlinearly Related in Wealth Effects?, "Munich Personal RePEc Archive" 2012, pp. 1-31, https://mpra.ub.uni-muenchen.de/id/eprint/36899 (access: 17.06.2021).

Bayar Y., Alakbarov N., Corruption and Foreign Direct Investment Inflows in Emerging Market Economies, "Ecoforum" 2016, 5(2), pp. 303-308, http://www.ecoforumjournal. ro/index.php/eco/article/view/431 (access: 17.06.2021).

Bearfield A.D., What Is Patronage? A Critical Reexamination, "Public Administration Review" 2009, 69(1), pp. 64-76, https://doi.org/10.1111/j.1540-6210.2008.01941.x.

Belgibayeva A., Plekhanov A., Does Corruption Matter for Sources of Foreign Direct Investment?, "Review of World Economics" 2019, 155(1), pp. 487-510, https://doi.org/10.1007/ s10290-019-00354-1.

Bentzen J.S., How Bad Is Corruption? Cross-country Evidence of the Impact of Corruption on Economic Prosperity, "Review of Development Economics" 2012, 16(1), pp. 164-187, https://doi.org/10.1111/j.1467-9361.2011.00653.x. 
Clausen B., Kraay A., Nyiri Z., Corruption and Confidence in Public Institutions: Evidence from a Global Survey, "The World Bank Economic Review” 2011, 25(1), pp. 212-249, https://doi.org/10.1093/wber/lhr018.

Cochran W.G., Sampling Techniques, 3rd ed., New York 1977.

Cronbach L.J., Coefficient Alpha and the Internal Structure of Tests, "Psychometrika" 1951, 16, pp. 297-334, https://doi.org/10.1007/BF02310555.

Dahlström C., Bureaucracy and Corruption, [in:] P.M. Heywood (ed.), Routledge Handbook of Political Corruption, Routledge 2014, pp.110-120, https://doi.org/10.4324/9781315739175.

Dornyei Z., Taguchi T., Questionnaires in Second Language Research: Construction, Administration and Processing, 2nd ed., New York 2010.

Gil-Pareja S., Llorca-Vivero R., Martínez-Serrano J.A., Corruption and International Trade: A Comprehensive Analysis With Gravity, "Applied Economic Analysis" 2019, 27(79), pp. 3-20, https://doi.org/10.1108/AEA-06-2019-0003.

Heywood P.M. (ed.), Routledge Handbook of Political Corruption, Routledge 2014, https:// doi.org/10.4324/9781315739175.

Hough D., Corruption, Anti-Corruption and Governance, [in:] P.M. Heywood, D. Hough (eds.), Political Corruption and Governance, Palgrave-Macmillan 2013, https:/doi. org/10.1057/9781137268716.

Hindess B., Good Government and Corruption, [in:] P. Larmour, N. Wolanin (eds.), Corruption and Anti-corruption, Canberra 2013, http://dx.doi.org/10.22459/CAC.03.2013.01.

Ivanyna M., Mourmouras A., Rangazas P., The Macroeconomics of Corruption. Governance and Growth, "Springer Texts Business, Economics" 2018, 1(1), https://doi.org/10.1007/9783-319-68666-0.

Kratcoski C.P., Edelbacher M. (eds.), Fraud and Corruption, Cham 2018, https://doi. org/10.1007/978-3-319-92333-8.

Larmour P., Wolanin N. (eds.), Corruption and Anti-Corruption, Canberra 2013, http:// doi.org/10.22459/CAC.03.2013.

Manacorda S., Centonze F., Forti G., Preventing Corporate Corruption: The Anti-Bribery Compliance Model, Springer 2014, https://doi.org/10.1007/978-3-319-04480-4.

Maruichi D., Abe M., Corruption and the Business Environment in Vietnam: Implications from an Empirical Study, "Asia and the Pacific Policy Studies" 2019, 6(2), pp. 222-245, https://doi.org/10.1002/app5.275.

Menocal A.R., Taxell N., Why Corruption Matters: Understanding Causes, Effects and How to Address Them: Evidence Paper on Corruption, Department for International Development [UK], January 2015, https://www.gov.uk/government/publications/why-corruption-matters-understanding-causes-effects-and-how-to-address-them (access: 17.06.2021).

Murray T., Corruption in Developing Countries: What Keeping It in the Family Means for Everyone Else, "Osgoode Hall Law Journal" 2015, 53(1), pp. 268-300, https://digitalcommons.osgoode.yorku.ca/ohlj/vol53/iss1/8 (access: 17.06.2021). 
Mudacumura G.M., Multiple Dimensions of Governance, [in:] G.M. Mudacumura, G. Morçöl (eds.), Challenges to Democratic Governance in Developing Countries, Public Administration, Governance and Globalization, Vol. 11, Cham 2014, https://doi. org/10.1007/978-3-319-03143-9_1.

Nwankwo F.O., Impact of Corruption on Economic Growth in Nigeria, "Mediterranean Journal of Social Sciences" 2014, 5(6), pp. 41-46, https://doi.org/10.5901/mjss.2014. v5n6p41.

Olken A.B., Pande R., Corruption in Developing Countries, "Annual Review of Economics" 2012, 4(1), pp. 479-509, https://doi.org/10.1146/annurev-economics-080511-110917.

Ozsahin S., Ucler G., The Consequences of Corruption on Inflation in Developing Countries: Evidence From Panel Cointegration and Causality Tests, "Economies" 2017, 5(4), pp. 1-15, https://doi.org/10.3390/economies5040049.

Quazi M.R., Corruption and Foreign Direct Investment in East Asia and South Asia: An Econometric Study, "International Journal of Economics and Financial Issues" 2014, 4(2), pp. 231-242, https://www.econjournals.com/index.php/ijefi/article/view/695 (access: 17.06.2021).

Ravelo L.J., 30 Percent of Aid Lost to Corruption - Ban Ki-moon, "The Development Newswire" [blog] 10.07.2012, www.devex.com/news/30-percent-of-aid-lost-to-corruption-ban-ki-moon-78643 (access: 17.06.2021).

Richey S., The Impact of Corruption on Social Trust, "American Politics Research" 2010, 38(4), pp. 676-690, https://doi.org/10.1177/1532673X09341531.

Sahakyan N., Stiegert K.W., Corruption and Firm Performance, "Eastern European Economics" 2012, 50(6), pp. 5-27, https://doi.org/10.2753/EEE0012-8775500601.

Sanchez A., Criminal Entrepreneurship: A Political Economy of Corruption and Organized Crime in India, [in:] P.M. Heywood (ed.), Routledge Handbook of Political Corruption, Routledge 2014, pp. 67-76, https://doi.org/10.4324/9781315739175.

Schoor V.B., Fighting Corruption Collectively: How Successful Are Sector-Specific Coordinated Governance Initiatives in Curbing Corruption?, Wiesbaden 2017, https://doi.org/10.1007/9783-658-17838-3.

Seumas M. (eds.), Corruption and Anti-Corruption in Policing - Philosophical and Ethical Issues, Springer 2016, https://doi.org/10.1007/978-3-319-46991-1.

Sylla K., Defining Corruption in the Cultural Context of Sub-Saharan Africa, [in:] G.M. Mudacumura, G. Morçöl (eds.), Challenges to Democratic Governance in Developing Countries, Public Administration, Governance and Globalization, Vol. 11, Cham 2014, https://doi.org/10.1007/978-3-319-03143-9_11.

Tingting L., Yu L., Barkat U., Zuobao W., Lixin C.X., The Dark Side of Transparency in Developing Countries: The Link Between Financial Reporting Practices and Corruption, "Journal of Corporate Finance" 2021, https://doi.org/10.1016/j.jcorpfin.2020.101829. The World Bank, Corruption from the Perspective of Citizens, Firms, and Public Officials, 2nd ed., National Political Publishing House 2013, http://documents1.worldbank. 
org/curated/en/989741468133546312/pdf/738070REVISED0000January02013000ENG. pdf (access: 17.06.2021).

United Nations, United Nations Convention against Corruption, 2004, https://www.unodc. org/documents/brussels/UN_Convention_Against_Corruption.pdf (access: 17.06.2021). Uslaner E.M., The Consequences of Corruption, [in:] P.M. Heywood (ed.), Routledge Handbook of Political Corruption, Routlege 2014,pp.199-211,https://oi.org/10.4324/9781315739175. Worthy B., McClean T., Freedom of Information and Corruption, [in:] P.M. Heywood (ed.), Routledge Handbook of Political Corruption, Routlege 2014, pp. 347-358, https://doi. org/10.4324/9781315739175. 